Bull. Chem. Soc. Ethiop. 2017, 31(3), 499-508.

ISSN 1011-3924

(c) 2017 Chemical Society of Ethiopia and The Authors

Printed in Ethiopia

DOI: http://dx.doi.org/10.4314/bcse.v31i3.14

\title{
SYNTHESIS OF TETRACATIONIC ORGANIC SALT FROM 4,4'-BIPYRIDINE
}

Atakilt Abebe ${ }^{*}$ and Minaleshewa Atlabachew

Chemistry Department, Science College, Bahir Dar University, Bahir Dar, Ethiopia

(Received November 18, 2016; Revised December 20, 2017; Accepted December 21, 2017)

ABSTRACT. This report describes the synthesis of a tetracationic organic salt from 4,4'-bipyridine and 1bromooctane using 1,3-dibromopropane as a spacer just in three simple steps. A careful monooctylation of one of the nitrogen atoms of 4,4'-bipyridine using 1-bromoocatane followed by the dimeriztion using 1,3dibromopropane as a linker resulted a tetracationic organic salt of formula $\left[\mathrm{C}_{3} \mathrm{H}_{6}\left(\mathrm{C}_{8} \mathrm{Bipyr}_{2}\right] \mathrm{Br}_{4} .{ }^{1} \mathrm{H}\right.$ and ${ }^{13} \mathrm{C} \mathrm{NMR}$, and CHN elemental analysis as well as ultra high vacuum spectroscopic technique (XPS) were employed to confirm the synthesis and the purity of this compound. This compound has demonstrated molar conductivity of $4320 \mathrm{~S} \mathrm{~cm}^{2} \mathrm{~mol}^{-1}$ unexpected from a salt with 1:4 cation to anion ratio. It is expected that this salt would have potential applications in materials such as for low-molecular-weight gelators and the preparation of solid films for organic electronic applications.

KEY WORDS: 4,4'-Bipyridine, Tetracationic, 1,3-bis(N-octyl-4,4'-bipyridine)propanium

\section{INTRODUCTION}

4,4'-Bipyridine is an ideal connector between any units having Lewis acidic sites (atoms) for network formation. This is because of its two potential binding nitrogen atoms with lone pair of electrons which are arranged in a divergent fashion as well as its rigid structure. Furthermore, it is convenient enough to create predictable molecular dimensions upon the formation of the networks. Even though the pyridine groups of 4,4'-bipyridine freely rotate along a central $\mathrm{C}-\mathrm{C}$ bond, it does not affect the mutual orientation of the two lone pairs. Therefore, 4,4'-bipyridine can be regarded as rigid and a prototypical bridging heteromolecule [1].

The synthesis and applications of polycationic organic salts has become one of the research directions of pure chemistry and material science. The chemistry and applications of monocationic organic salts has been the starting points for this progress. The majority of the later compounds are known as ionic liquids. Ionic liquids (ILs) are low temperature melting salts (below $100{ }^{\circ} \mathrm{C}$ ) [2, 3]. These have been widely used as alternative reaction media to conventional organic solvents [4-6] and in electrochemistry [7, 8]. Evolved from the latter, di-, tri- and tetracationic organic salts have become ideal materials in solving several problems [9]. This is due to the potential to change their structural features simply by: varying the nature of the cation and/or the anion; tuning them by introducing small structural changes in the constituting ions, or of the spacers separating them provides the opportunity to obtain materials with sets of desired properties suitable for different applications. They have been applied as a chemical anchorage on a solid support [10], starting materials for the synthesis of molecular devices [11, 12], reaction media or catalysts, immobilization of catalysts [9], reaction media for high-temperature organic reactions [13, 14], catalysts [15], receptors for anion recognition [16], low-molecular-weight gelators [17], fluorescent organic salts [18,19], energetic materials [20, 21], for use in the preparation of solid films for organic electronic applications [22] and electrowetting materials [23]. Heteromolecules including imidazole, 1,10-phenanthroline, pyridine and others have been used as the starting materials for the synthesis of polycationic organic salts. 4,4'-bipyridine has a convenient structure to serve as a precursor for the synthesis

*Corresponding author. E-mail: atakiltabebe1@gmail.com, atminale2004@yahoo.com

This work is licensed under the Creative Commons Attribution 4.0 International License 
of polycharged organic salts. Several reports appeared in literature describing the synthesis and applications of organic salts derived from 4,4'-bipyridine [3, 24-29]. In this regard, tetracationic salts derived from 4,4'-bipyridine have been reported using ethylbromide as primary quaternizing and $\mathrm{X}\left(\mathrm{CH}_{2}\right)_{\mathrm{n}} \mathrm{X}, \mathrm{n}=4-10$ as spacers [30-32]. The nature and compositions of the first quaternizing and the spacer alkyl chain significantly influence the characteristics of the polycharged salt. In this report, therefore, we demonstrate the synthesis and characterizations of a new tetracationic organic salt using 4,4'-bipyridine, $\mathrm{CH}_{3}\left(\mathrm{CH}_{2}\right)_{6} \mathrm{CH}_{2} \mathrm{Br}$ as a primary quaternizing molecule and $\mathrm{Br}\left(\mathrm{CH}_{2}\right)_{3} \mathrm{Br}$ as a linker with bromide as a counter anion. The latter is responsible for the high solubility of the salt in water and other polar solvents such as methanol and acetonitrile.

The primary step, which is important to acquire the target tetracationic organic salt, relies up on the successful quaternization of one of the equally active nitrogen atoms in 4,4'-bipyridine by $\mathrm{CH}_{3}\left(\mathrm{CH}_{2}\right)_{6} \mathrm{CH}_{2} \mathrm{Br}$. This gives a monocationic $\mathrm{N}$-octyl-4,4'-bipyridinium bromide as a product [3]. The symmetry of 4,4'-bipyridine is reduced following the quaternization of only one of its nitrogen atoms and this new characteristic feature helps in the identification of the new monocationic organic salt as new peaks appear in both the ${ }^{1} \mathrm{H}$ and ${ }^{13} \mathrm{C}$ NMR spectra. The careful 1:2 molar ratio treatment of this product with 1,3-dibromopropane yielded bis(N-octyl-4,4'bipyridine)propanium bromide.

\section{EXPERIMENTAL}

\section{Materials and methods}

All chemicals used in the present work, viz., 4,4'-bipyridine (99\%), 1-bromooctane, 1,3dibromopropane (99\%), 1,4-dioxane, acetonitrile are all from Sigma-Aldrich and are used as received.

The structures of the prepared compounds were confirmed by their ${ }^{1} \mathrm{H}$ NMR, and ${ }^{13} \mathrm{C}$ NMR using a Bruker AM-270 (270 MHz) spectrometer dissolving in deuterated dimethyl sulfoxide. CHN elemental analysis was done using 5E-CHN2200 Elemental Analyzer taking $15 \mathrm{mg}$ sample. Bromide estimation was conducted taking $1 \mathrm{mg}$ sample dissolved in $20 \mathrm{~mL}$ distilled water. Excess $\mathrm{AgNO}_{3}$ solution was added for the formation of silver bromide (AgBr) precipitate. Then the cruddy white precipitate formed was filtered, dried in an oven and the amount of bromide was calculated from the weight difference. The electronic environment of the component atoms of the cation, $\left[\mathrm{C}_{3} \mathrm{H}_{6}\left(\mathrm{C}_{8} \text { Bipyr }\right)_{2}\right]^{4+}$ and the anion, bromide, $\left(\mathrm{Br}^{-}\right)$were investigated using ultra-high vacuum (UHV) characterization using $\mathrm{X}$-ray photoelectron spectroscopy, XPS. The X-ray photoelectron spectra were recorded using a Kratos Axis Ultra spectrometer employing a focused, monochromated Al $\mathrm{K} \alpha$ source ( $\mathrm{h} v=1486.6 \mathrm{eV}$ ), hybrid (magnetic/electrostatic) optics, hemispherical analyzer and a multi-channel plate and delay line detector (DLD) with an X-ray incident angle of $0^{\circ}$ (relative to the surface normal). The spectrum was processed without charge correction. Its conductivity for $10^{-4} \mathrm{M}$ solution in deionized water was also investigated using JENWAY 4200 conductivity meter at room temperature with cell constant of 0.96 .

\section{Synthesis of $N$-octyl-4,4'-bipyridinium bromide, $\left[C_{8}\right.$ Bipyr $] \mathrm{Br}$}

$5 \mathrm{~g}(0.032 \mathrm{~mol})$ of 4,4'-bipyridine was dissolved in $30 \mathrm{~mL}$ dry 1,4-dioxane in a two necked 100 $\mathrm{mL}$ round bottomed flask fitted with a condenser. $6.20 \mathrm{~g}(0.032 \mathrm{~mol}, 5.55 \mathrm{~mL})$ of 1bromooctane dissolved in $10 \mathrm{~mL}$ dry 1,4-dioxanewas added drop wise from a dropping funnel and the mixture was allowed to stir at $65{ }^{\circ} \mathrm{C}$. After $24 \mathrm{~h}$, a pale yellow precipitate was filtered from the reaction medium and characterized by ${ }^{1} \mathrm{H}$ and ${ }^{13} \mathrm{C}$ NMR spectroscopy. The result revealed that the product contained a mixture of monoalkylated and dialkylated 4,4'bipyridinium bromides. $50 \mathrm{~mL}$ chloroform was used to extract the dialkylated product from the 
mixture. After filtration the chloroform was removed by evaporation in vacuo and the resulting solid dried under high vacuum for 4 hours. A white powder $\left[\mathrm{C}_{8} \mathrm{Bipyr}\right] \mathrm{Br}$ was collected (yield $8.56 \mathrm{~g}, 76.5 \%$ [3].

\section{Synthesis of 1,3-Bis-(N-Octyl-4,4'-bipyridinpropanium bromide, $\left[\mathrm{C}_{3} \mathrm{H}_{6}\left(\mathrm{C}_{8} \mathrm{Bipyr}_{2}\right] \mathrm{Br}_{4}\right.$}

$2 \mathrm{~g}(0.0057 \mathrm{~mol})$ of $\left[\mathrm{C}_{8} \mathrm{Bipyr}\right] \mathrm{Br}$ was dissolved in $50 \mathrm{~mL}$ dry acetonitrile in a two necked 250 $\mathrm{mL}$ round bottomed flask fitted with a condenser. $0.605 \mathrm{~g}(0.003 \mathrm{~mol}, 306 \mu \mathrm{L}$, slightly excess $)$ of 1,3-dibromopropane $\left(\mathrm{Br}\left(\mathrm{CH}_{2}\right)_{3} \mathrm{Br}\right)$ dissolved in $20 \mathrm{~mL}$ acetonitrile was added from a dropping funnel and the mixture was allowed to stir at $70{ }^{\circ} \mathrm{C}$. After 72 hours bright yellow precipitate was filtered from the reaction medium and washed three times in $20 \mathrm{~mL}$ acetonitrile each and dried under high vacuum for 4 hours (yield $4.44 \mathrm{~g}, 86 \%$ ). The reaction path is indicated in Scheme 1.

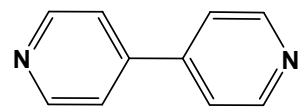

4, 4'-Bipyridine

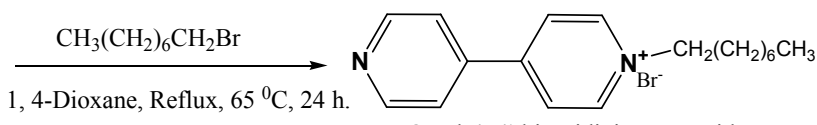

N-Octyl-4, 4'-bipyridinium Bromide $\left(\left[\mathrm{C}_{8}\right.\right.$ Bipyr $\left.\left.] \mathrm{Br}\right]\right)$
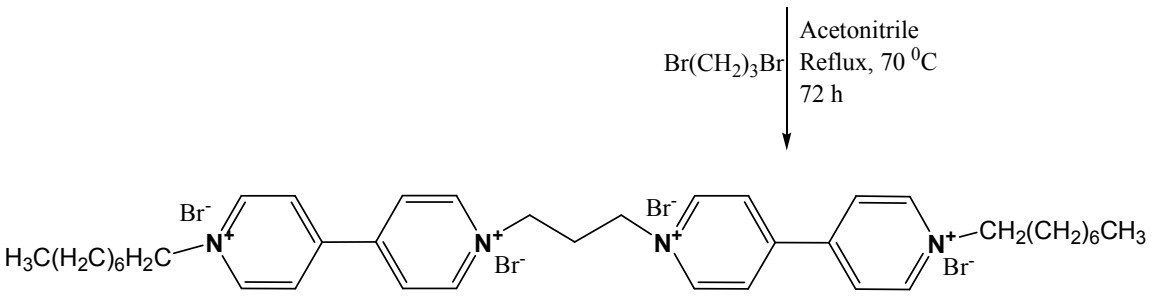

1, 3-Bis-(N-Octyl-4, 4'-bipyridinepropanium) Bromide

$\left(\left[\mathrm{C}_{3} \mathrm{H}_{6}\left(\mathrm{C}_{8} \text { bipyr }\right)_{2}\right] \mathrm{Br}_{4}\right)$

Scheme 1 . The synthetic strategy of $\left[\mathrm{C}_{3} \mathrm{H}_{6}\left(\mathrm{C}_{8} \mathrm{Bipyr}\right)_{2}\right] \mathrm{Br}_{4}$.

\section{RESULTS AND DISCUSSION}

Characterization of $\mathrm{N}$-Octyl-4,4'-bipyridinium bromide, $\left[\mathrm{C}_{8}\right.$ Bipyr $] \mathrm{Br}$

${ }^{1} \mathrm{H}$ NMR $\left(270 \mathrm{MHz}, \mathrm{DMSO}-d_{6}\right) \delta \mathrm{ppm} 0.78-0.87(\mathrm{~m}, 3 \mathrm{H}), 1.16-1.35(\mathrm{~m}, 10 \mathrm{H}), 1.96(\mathrm{~d}, J=5.92$ $\mathrm{Hz}, 2 \mathrm{H}), 4.70(\mathrm{t}, J=7.44 \mathrm{~Hz}, 2 \mathrm{H}), 8.05-8.11(\mathrm{~m}, 2 \mathrm{H}) 8.67-8.72(\mathrm{~m}, 2 \mathrm{H}), 8.82-8.88(\mathrm{~m}, 2 \mathrm{H})$, $9.35(\mathrm{~d}, J=7.02 \mathrm{~Hz}, 2 \mathrm{H}) .{ }^{13} \mathrm{C}$ NMR $\left(68 \mathrm{MHz}, \mathrm{DMSO}-d_{6}\right) \delta \mathrm{ppm} 14.50$ (s, 1C), 22.61 (s, 1C), 25.99 (s, 1C), 29.00 (d, 2C), 31.28-31.79 (m, 2C), 60.80 (s, 1C), 121.82 (s, 1C), 122.50 (s, 2C), 125.94 (s, 1C), 141.37 (s, 1C), 145.91 (s, 1C), 148.22-154.23 (m, 2C), 149.90-156.39 (m, 2C), (CHN elemental analysis: found(calculated), C, 61.86(61.89), H, 7.15(7.16), N, 7.96(8.02), Br, 22.88(22.92).

Characterization of $\left[\mathrm{C}_{3} \mathrm{H}_{6}\left(\mathrm{C}_{8} \text { Bipyr }\right)_{2}\right] \mathrm{Br}_{4}$

${ }^{1} \mathrm{H}$ NMR (270 MHz, DMSO- $\left.d_{6}\right) \delta$ ppm 0.82-0.90 (m, 6H), 0.83-0.88 (m, $\left.6 \mathrm{H}\right), 1.19-1.41$ (m, $18 \mathrm{H}), 1.99(\mathrm{~s}, J=0.28 \mathrm{~Hz}, 6 \mathrm{H}), 2.77-2.90(\mathrm{~m}, 3 \mathrm{H}), 2.80-2.89(\mathrm{~m}, 3 \mathrm{H}), 4.72(\mathrm{t}, J=7.23 \mathrm{~Hz}, 6 \mathrm{H})$, $4.95(\mathrm{t}, J=7.02 \mathrm{~Hz}, 4 \mathrm{H}), 8.90(\mathrm{dd}, J=14.60,6.89 \mathrm{~Hz}, 12 \mathrm{H}), 9.42-9.61(\mathrm{~m}, 12 \mathrm{H})$ (Figure 1$).{ }^{13} \mathrm{C}$ 
NMR (68 MHz, DMSO- $d_{6}$ ) $\delta$ ppm $14.53(\mathrm{~s}, 2 \mathrm{C}), 22.63$ (s, 2C), 26.03 (s, 2C), 29.00 (d, 4C) 31.31-31.75 (m, 3C), 127.20 (d, 4C), 146.55 (d, 3C), 148.92-149.33 (m, 1C) (Figure 2).
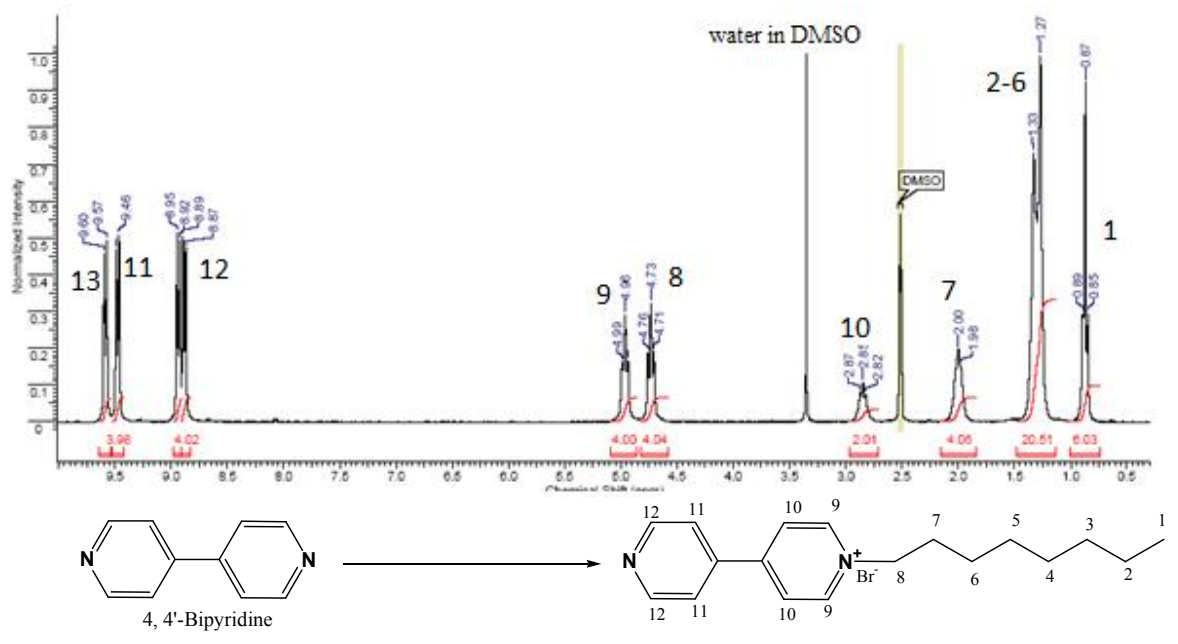

N-Octyl-4, 4'-bipyridinium Bromide

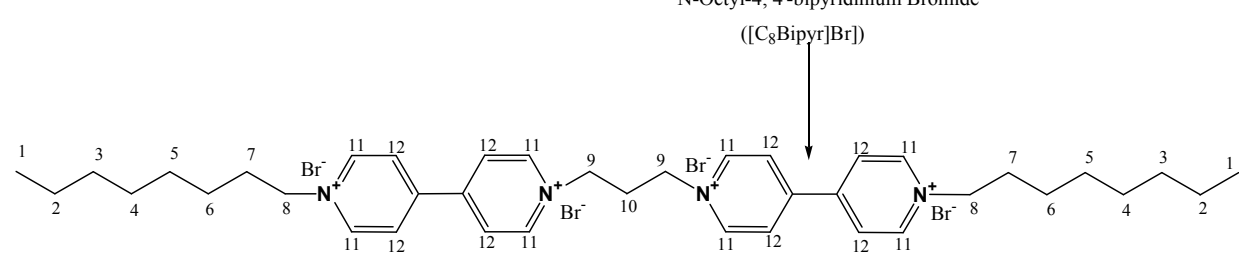

1, 3-Bis-(N-Octyl-4, 4'-bipyridinepropanium) Bromide

$\left(\left[\mathrm{C}_{3} \mathrm{H}_{6}\left(\mathrm{C}_{8} \text { bipyr }\right)_{2}\right] \mathrm{Br}_{4}\right)$

Figure 1. 1H NMR spectrum of $\left[\mathrm{C}_{3} \mathrm{H}_{6}\left(\mathrm{C}_{8} \mathrm{Bip}\right)_{2}\right] \mathrm{Br}_{4}$ with the corresponding assignment of the chemical shift.

\section{CHN elemental analysis}

Element, found(calculated), C, 51.96(52.00), H, 6.15(6.22), N, 6.10(6.22), Br, 35.50(35.56). The composition and purity of the compound were established by the measurement of XP survey (Figure 3) and high-resolution spectra (Figures 4-6).

The electronic environments of the component atoms in $\mathrm{eV}: 284.929$ for $\mathrm{C} 1 \mathrm{~s}$ of the fourteen carbons from the octane residues, 286.835 for $\mathrm{C} 1 \mathrm{~s}$ of the carbons linked to the ring nitrogens, 285.601 for $\mathrm{C} 1 \mathrm{~s}$ of ring carbons not attached to nitrogen, 285.625 for $\mathrm{C} 1 \mathrm{~s}$ of the middle carbon in the spacer (Figure 3 and 4), 286.835 for N1s (Figure 3 and 5). For bromine, 67.3275 and 68.376 for $3 \mathrm{~d} 5 / 2$ and $3 \mathrm{~d} 3 / 2$, respectively) (Figures 3 and 6 ).

The dimerization of the $\left[\mathrm{C}_{8} \mathrm{Bip}\right] \mathrm{Br}$ using $\mathrm{Br}\left(\mathrm{CH}_{2}\right)_{3} \mathrm{Br}$ as a spacer to $\left[\mathrm{C}_{3} \mathrm{H}_{6}\left(\mathrm{C}_{8} \mathrm{Bipyr}\right)_{2}\right] \mathrm{Br}_{4}$ is evident in the ${ }^{1} \mathrm{H}$ NMR from the appearance of two new peaks centered at $\delta \mathrm{ppm}=4.95(\mathrm{t})$ and $2.85(\mathrm{~m})$ with peak area equivalent to four and two protons, respectively. Moreover, those peaks observed in the precursor monoalkylated organic salt also are found peak areas doubled in the final compound (Figure 1). Similar confirmations are obtained in the ${ }^{13} \mathrm{C}$ NMR (Figure 2). 


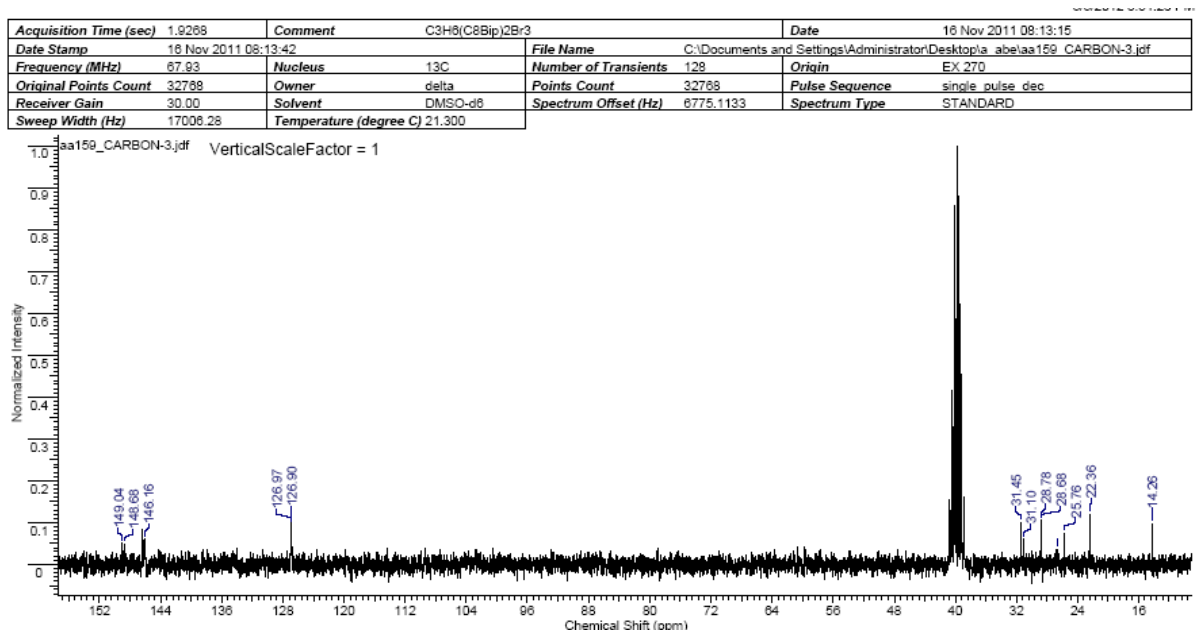

Figure 2. ${ }^{13} \mathrm{C}$ NMR spectrum of $\left[\mathrm{C}_{3} \mathrm{H}_{6}\left(\mathrm{C}_{8} \mathrm{Bip}\right)_{2}\right] \mathrm{Br}_{4}$

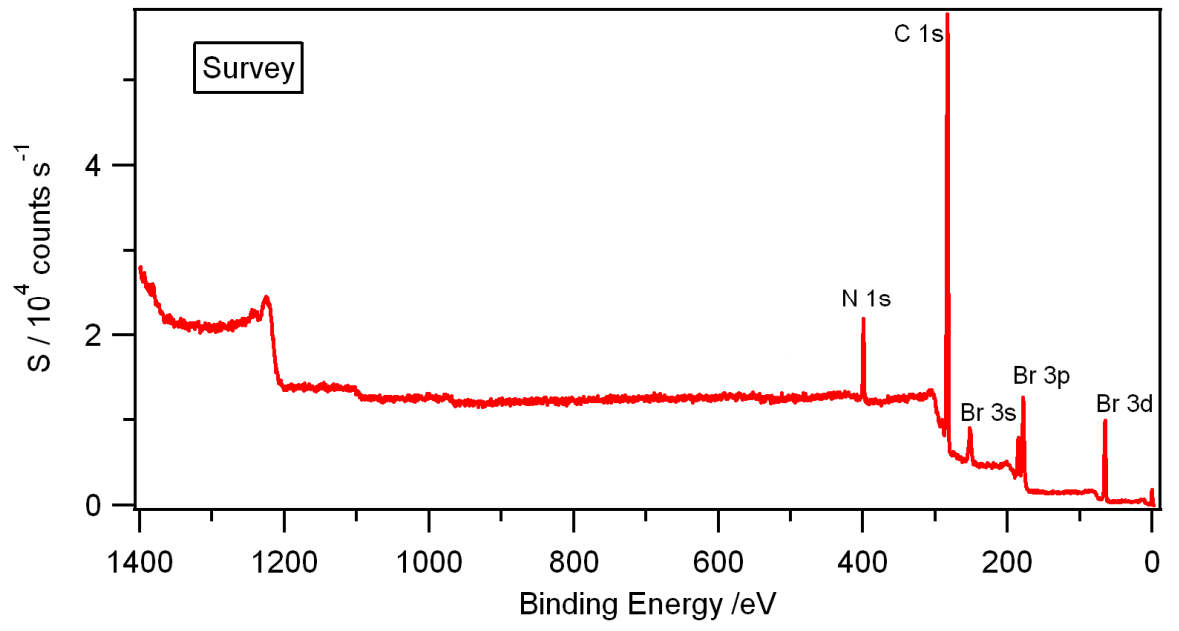

Figure 3. XP survey spectrum of $\left[\mathrm{C}_{3} \mathrm{H}_{6}\left(\mathrm{C}_{8} \mathrm{Bip}_{2}\right] \mathrm{Br}_{4}\right.$.

The survey of spectrum from the XPS showed the purity of the compound which compounded the evidence from the CHN elemental analysis. From the XPS spectra, the electronic environments identified were, only one for all the nitrogens resonated at $401.788 \mathrm{eV}$, four for carbons and one for bromide. All the carbons linked to the ring nitrogens formed the same electronic environment with a binding energy of $286.835 \mathrm{eV}$. The remaining ring carbons constituted the second electronic environment with binding energy of $285.601 \mathrm{eV}$. The middle carbon in the spacer showed a different electronic environment resonating at $285.625 \mathrm{eV}$ where as the fourteen carbons from the octane residues formed the fourth electronic environment with binding energy of $284.929 \mathrm{eV}$. The maximum molar conductivity of a salt with 1:4 cation to anion or vice versa in water at $298 \mathrm{~K}_{\text {is }} 736 \mathrm{~S} \mathrm{~cm}^{-2} \mathrm{~mol}^{-1}$ [33]. However, this salt demonstrated 
attractive molar conductivity $\left(4320 \mathrm{~S} \mathrm{~cm}^{2} \mathrm{~mol}^{-1}\right)$. This is attributed to the high speed of mobility of the ions due to the nature of the cation. This is a consequence of the very long dimeric, rodlike cation contained relatively long hydrophobic alkyl chain; its positive charge is highly delocalized throughout the aromatic ring portion; subsequently, become amphiphilic [30]. This reduces the drifting (counter directional) speed due to the interaction with the solvent cavity surrounding the cation.
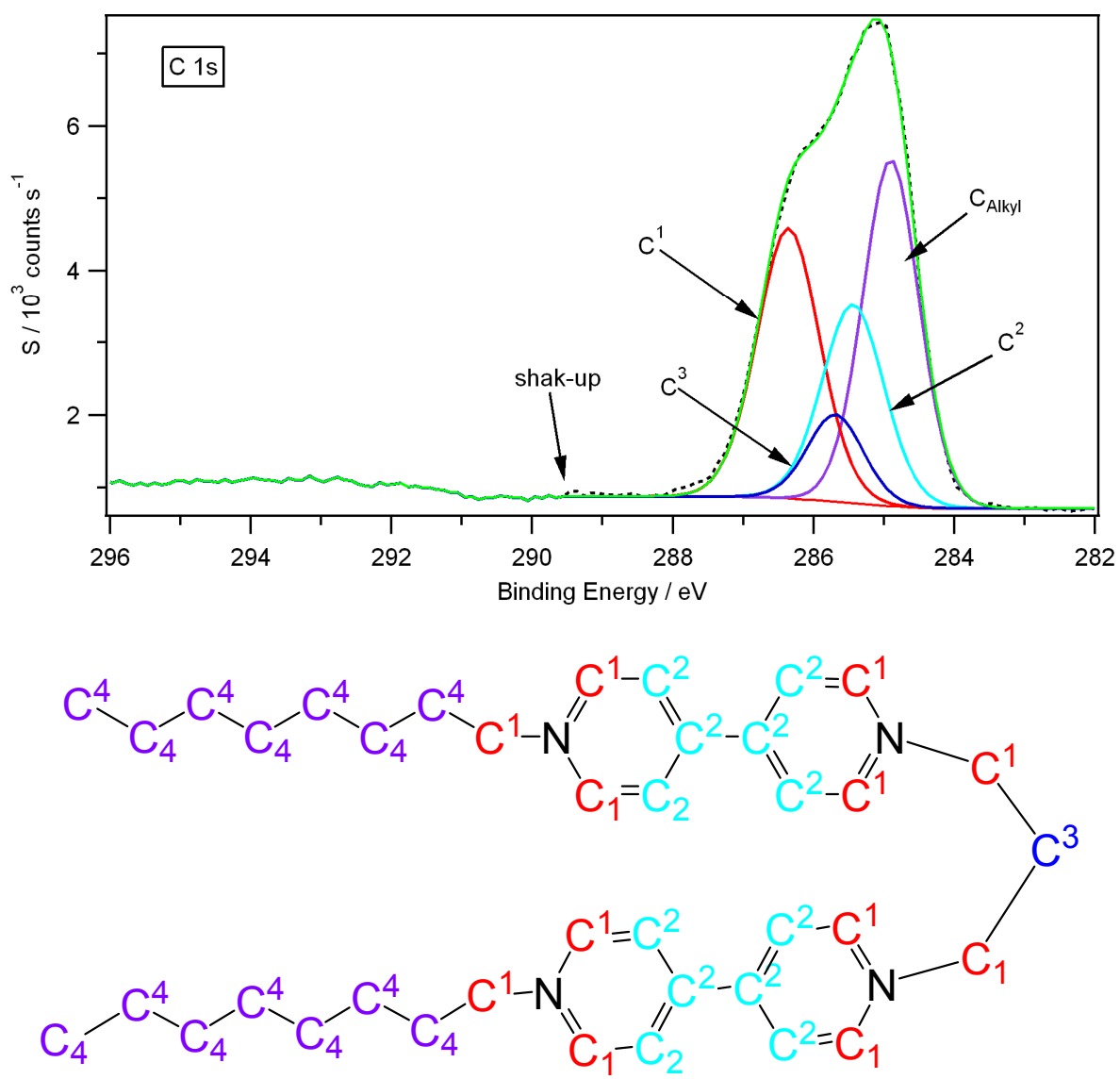

Figure 4. C1s XP spectrum with component fittings of $\left[\mathrm{C}_{3} \mathrm{H}_{6}\left(\mathrm{C}_{8} \mathrm{Bip}\right)_{2}\right] \mathrm{Br}_{4}$. 


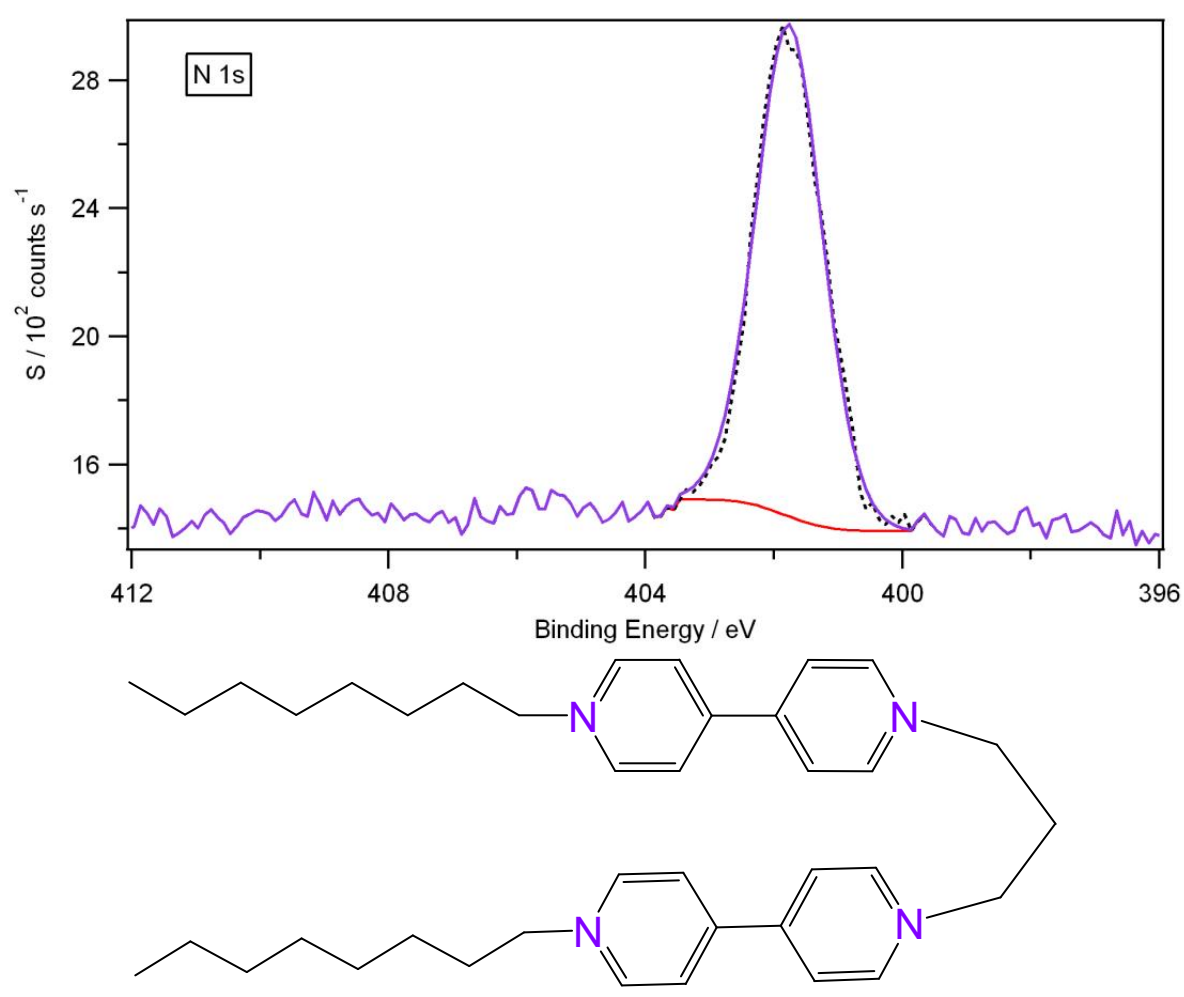

Figure 5. N1s XP spectrum with component fittings of $\mathrm{C}_{3} \mathrm{H}_{6}\left(\mathrm{C}_{8} \mathrm{Bip}_{2} \mathrm{Br}_{4}\right.$.

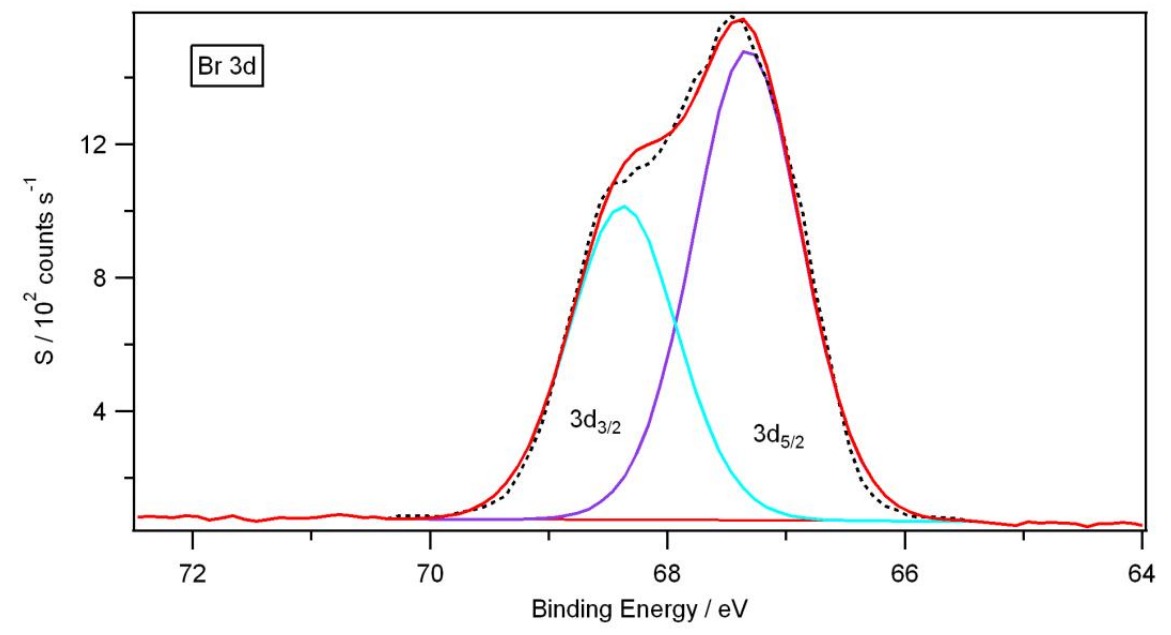

Figure 6. $\mathrm{Br} 3 \mathrm{~d}_{5 / 2}$ and $3 \mathrm{~d}_{3 / 2} \mathrm{XP}$ spectrum with component fittings of $\left[\mathrm{C}_{3} \mathrm{H}_{6}\left(\mathrm{C}_{8} \mathrm{Bip}\right)_{2}\right] \mathrm{Br}_{4}$. Bull. Chem. Soc. Ethiop. 2017, 31(3) 


\section{CONCLUSION}

A new tetra cationic organic salt is synthesized from new moieties following techniques that ensure purity as well as acceptable yield. The result increases the number and type of polycationic organic salts at least by one. This creates opportunities to the scientific community to investigate its applications in different areas such as catalysts receptors, for anion recognition, low-molecular-weight gelators, as energetic materials, for use in the preparation of solid films for organic electronic applications to mention a few.

\section{ACKNOWLEDGEMENTS}

The authors would like to acknowledge Bahir Dar University, Ethiopia for funding this research. We are indebted to Dr. Emily Smith from the School of Chemistry, University of Nottingham, UK, for assistance with XPS data collection.

\section{REFERENCES}

1. Bâldea, I.; Köppel, H.; Wenzel, W. $\left(4,4^{\prime}\right)$-Bipyridine in vacuo and in solvents: A quantum chemical study of a prototypical floppy molecule from a molecular transport perspective. Phys. Chem. Chem. Phys. 2013, 15, 1918-1928.

2. Villar-Garcia, I.J.; Abebe, A; Chebude, Y. 1,10-Phenanthrolinium ionic liquids exhibiting excellent solubility for metal complexes: Potential solvents for biphasic and supported ionic liquid phase (SILP) catalysis. Inorg. Chem. Commun. 2012, 19, 1-3.

3. Abebe, A.; Admassie, S.; Villar-Garcia, I.J; Chebude, Y. 4,4-Bipyridinium ionic liquids exhibiting excellent solubility for metal salts: Potential solvents for electrodeposition. Inorg. Chem. Commun. 2013, 29, 210-212.

4. Weber, C.C.; Masters, A.F; Maschmeyer, T. Structural features of ionic liquids: Consequences for material preparation and organic reactivity. Green Chem. 2013, 15, 26552679.

5. Hu, L.; Xie, B.; Li, J. Efficient Baeyer-Villiger electro-oxidation of ketones with molecular oxygen using an activated carbon fiber electrode in ionic liquid [bmim][OTf]. Bull. Chem. Soc. Ethiop. 2016, 30, 297-306.

6. Yao, L.; Liu, S.; Li, L.; Yu, S.; Liu, F; Song, Z. Synthesis of hydroxymethylfurfural from sucrose using Brönsted-Lewis acidic ionic liquid. Bull. Chem. Soc. Ethiop. 2016, 30, 283288.

7. Huang, H.Y.; Su, C.J.; Kao, C.L.; Chen, P.Y. Electrochemical study of Pt and Fe and electrodeposition of $\mathrm{PtFe}$ alloys from air-and water-stable room temperature ionic liquids. $J$. Electroanal. Chem. 2010, 650, 1-9.

8. Walsh, D.A.; Lovelock, K.R.; Licence, P. Ultramicroelectrode voltammetry and scanning electrochemical microscopy in room-temperature ionic liquid electrolytes. Chem. Soc. Rev. 2010, 39, 4185-4194.

9. D'Anna, F.; Noto, R. Di- and tricationic organic salts: An overview of their properties and applications. Eur. J. Org. Chem. 2014, 2014, 4201-4223.

10. Schneider, M.J.; Lijewski, M.; Woelfel, R.; Haumann, M.; Wasserscheid, P. Continuous gas phase hydroaminomethylation using supported ionic liquid phase catalysts. Angew. Chem. Int. Ed. 2013, 52, 6996-6999.

11. Coumans, R.G.; Elemans, J.A.; Rowan, A.E.; Nolte, R.J. Interlocked porphyrin switches. Chem. Eur. J. 2012, 19, 7758-7770. 
12. Jo, T.S.; McCurdy, W.L.; Tanthmanatham, O.; Kim, T.K.; Han, H.; Bhowmik, P.K.; Heinrich, B.; Donnio, B. Synthesis and characterization of luminescent tricationic salts of mesitylene and stilbazolium moieties. J. Mol. Struc. 2013, 1019, 174-182.

13. Anderson, J.L.; Ding, R.; Ellern, A.; Armstrong, D.W. Structure and properties of high stability geminal dicationic ionic liquids. J. Am. Chem. Soc. 2005, 127, 593-604.

14. Chinnappan, A.; Kim, H. Environmentally benign catalyst: Synthesis, characterization, and properties of pyridinium dicationic molten salts (ionic liquids) and use of application in esterification. Chem. Eng. J. 2012, 187, 283-288.

15. Jadhav, A.H.; Kim, H. Short oligo (ethylene glycol) functionalized imidazolium dicationic room temperature ionic liquids: Synthesis, properties, and catalytic activity in azidation. Chem. Eng. J. 2012, 200, 264-274.

16. Tak, V.; Pardasani, D.; Purohit, A.; Dubey, D.K. Detection and identification of alkylphosphonic acids by positive electrospray ionization tandem mass spectrometry using a tricationic reagent. Rapid Commun. Mass Spectrom. 2011, 25, 3411-3416.

17. Tu, T., Assenmacher, W.; Peterlik, H.; Schnakenburg, G.; Dötz, K.H. Pyridine-bridged benzimidazolium salts: Synthesis, aggregation, and application as phase-transfer catalysts. Angew. Chem. Int. Ed. 2008, 47, 7127-7131.

18. Boydston, A.J.; Pecinovsky, C.S.; Chao, S.T.; Bielawski, C.W. Phase-tunable fluorophores based upon benzobis(imidazolium)salts. J. Am. Chem. Soc. 2007, 129, 14550-14551.

19. Boydston, A.J.; Vu, P.D.; Dykhno, O.L.; Chang, V.; Wyatt, A.R.; Stockett, A.S.; Ritschdorff, E.T.; Shear, J.B.; Bielawski, C.W. Modular fluorescent benzobis(imidazolium) salts: Syntheses, photophysical analyses, and applications. J. Am. Chem. Soc. 2008, 130, 3143-3156.

20. Wang, R.; Gao, H.; Ye, C.; Shreeve, J.N.M. Strategies toward syntheses of triazolyl-or triazolium-functionalized unsymmetrical energetic salts. Chem. Mater. 2007, 19, 144-152.

21. Rao, M.H.; Muralidharan, K. Syntheses, characterization and energetic properties of closo(B12H12)2- salts of imidazolium derivatives. Dalton Trans. 2013, 42, 8854-8860.

22. Reilly, T.H.; Hains, A.W.; Chen, H.Y.; Gregg, B.A. A self-doping, O2-stable, n-type interfacial layer for organic electronics. Adv. Energy Mater. 2012, 2, 455-460.

23. Nanayakkara, Y.S.; Moon, H.; Payagala, T.; Wijeratne, A.B.; Crank, J.A.; Sharma, P.S.; Armstrong, D.W. A fundamental study on electrowetting by traditional and multifunctional ionic liquids: possible use in electrowetting on dielectric-based microfluidic applications. Anal. Chem. 2008, 80, 7690-7698.

24. Yu, L.P.; Samulski, E.T. In Oriented Fluids and Liquid Crystals, Vol. 4, Griffin, A.C.; Johnson, J.F. (Eds.), Plenum: New York; 1984; p 697.

25. Tabushi, I.; Yamamura, K.; Kominami, K. Electric stimulus-response behavior of liquidcrystalline viologen. J. Am. Chem. Soc. 1986, 108, 6409-6410.

26. Yamamura, K.; Okada, Y.; Ono, S.; Kominami, K.; Tabushit, I. New liquid crystalline viologens exhibiting electric stimulus-response behavior. Tetrahedron lett. 1987, 28, 64756478.

27. Haramoto, Y.; Yin, M.; Matukawa, Y.; Ujiie, S.; Nanasawa, M. A new ionic liquid crystal compound with viologen group in the principal structure. Liquid Crystals 1995, 19, 319-320.

28. Tahara, H.; Furue, Y.; Suenaga, C.; Sagara, T. A dialkyl viologen ionic liquid: X-ray crystal structure analysis of bis (trifluoromethanesulfonyl) imide salts. Crystal Growth Design 2015, 15, 4735-4740.

29. Kobayashi, T.; Ichikawa, T. Design of viologen-based liquid crystals exhibiting bicontinuous cubic phases and their redox-active behavior. Materials 2017, 10, 1-9.

30. Bonchio, M.; Carraro, M.; Casella, G.; Causin, V.; Rastrelli, F.; Saielli, G. Thermal behaviour and electrochemical properties of bis(trifluoromethanesulfonyl)amide and dodecatungstosilicate viologen dimers. Phys. Chem. Chem. Phys. 2012, 14, 2710-2717. 
31. Casella, G.; Causin, V.; Rastrelli, F.; Saielli, G. Viologen-based ionic liquid crystals: Induction of a smectic A phase by dimerisation. Phys. Chem. Chem. Phys. 2014, 16, 50485051.

32. Casella, G.; Causin, V.; Rastrelli, F.; Saielli, G. Ionic liquid crystals based on viologen dimers: Tuning the mesomorphism by varying the conformational freedom of the ionic layer. Liquid Crystals 2016, 43, 1161-1173.

33. Atkins, P.W. Physical Chemistry, 5th ed., Oxfored University Press: Oxford. 1994, pp 834841. 